\title{
REPRODUCTIVE CHARACTERISTICS OF SIMMENTAL BREED BULL DAMS $^{1}$
}

\author{
V. Pantelić, Z. Skalicki, M. M. Petrović, D. Kučević
}

Abstract: Cattle reproduction is most significant production phase because in this phase heads of cattle for maintaining of the herd are provided, as well as for dairy production and fattening - production of meat.

The effect of year and season of calving on age at first conception, duration of pregnancy, duration of service period, interval between calving, etc. is investigated in the paper. Bull dams of Simmental breed selected on farms of individual agricultural producers were investigated. The method of Least Squares LSMLMW(Harvey 1987) was used for analysis of the effect of year and season of calving on reproductive traits.

Year of calving had significant effect on duration of service period and interval between calving $(\mathrm{p}<0.05)$, while season influenced significantly only the duration of service period $(p<0.05)$. Mean values of the general average were following: for age at first conception - 517.61 days; duration of pregnancy 285.51 days; duration of service period 108.98 days; duration of interval between calving 395.34 days.

Key words: Reproduction, Simmental breed, bull dams, year and season of calving.

\section{Introduction and literature review}

Reproduction of cattle in modern livestock production represents very important field of research and complex production phase because

\footnotetext{
${ }^{1}$ Original scientific paper - Originalni naučni rad

2 Mr Vlada Pantelić, research assistant, Dr Milan M. Petrović, scientific counselor, Mr Denis Kučević, research trainee, Institute for Animal Husbandry, Belgrade-Zemun; Dr Zlatko Skalicki, full professor, Faculty of Agriculture, Zemun
} 
of the greatest reserves of milk, meat, breeding animals and by-products. At the same time this is production phase with many unsolved problems or problems that are not completely determined and defined, and solving of these problems should enable production of more high quality products for human nutrition, clothing and other needs.

Considering that economical importance of reproductive traits of dairy cattle is high knowledge of certain factors, genetic and paragenetic, affecting the cow fertility is necessary. Success in improvement of fertility through genetic factors is rather limited by low heritability values, this doesn't mean that genes have no effect on this trait but that value of additive genetic variation is low. Factors of the environment have greater effect on cow fertility since most of variations of reproductive traits are under the influence of these factors. Effect of certain individual factors on cow fertility can be of different degree, also complex influence is possible. Universal knowledge of many factors influencing certain reproductive traits can improve the cow fertility (Trifunović et al. 2004).

According to Lazarević et al. (1985) average duration of pregnancy of Simmental cows (236 females from I to V and more lactations) was 282,5 days. Age of heifers at first calving was in average 805 days. Duration of I service period was 154 days, II - 172, III - 146, IV -181 and V -158 days. Depending on the duration of service period, value of interval between 2 calvings varied from 435, 454, 430 to 464 days.

Spasić (1996) investigated variability and connection between milk and fertility traits of three generations of Domestic spotted cattle. Average age of heads in the first three conceptions was 698,$50 ; 1.228,67$; $1.691,1$ days respectively or calculated in months: 23,$28 ; 40,95 ; 56,37$. First three pregnancies lasted in average 283,71 days. Service period lasted 226,43 days, whereas the value of duration of interval between two clavings was 510,91 days.

Investigating the longevity and production of milk and milk fat of Simmental cows, Petrovic M. (2000) established average age at first conception of 574,34 days or 19,14 months. Cows calved for the first time in age of 28,56 months. Average duration of pregnancy was 285,52 days. Duration of service period in average was 130,63 days, and duration of interval between calvings was 416,76 days. The author didn't establish the significant effect of season of calving on duration of 
pregnancy $(\mathrm{P}>0,05)$, but significant influence of season of calving on duration of service period $(\mathrm{P}<0,05)$ was determined.

In the research of Skalicki et al. (1991) it was determined that season of calving had highly significant effect on age at first conception of cows. Significant effect $(\mathrm{P}<0,05)$ on age at first conception and duration of service period was also determined. Season of calving had no statistically significant effect on duration of pregnancy, intensity of fertility and mass of calves.

Investigating the effect of season of calving on fertility traits Trifunović et al. (2003) concluded that it had different effect on investigated traits. Highly significant effect was demonstrated on insemination index $(\mathrm{P}<0,01)$, significant effect on duration of pregnancy $(\mathrm{P}<0,05)$ whereas for other fertility traits (service period, interval between calvings and body mass of calves at birth) no significant effect could be determined.

\section{Material and Methods}

Investigation included 292 cows of Simmental breed selected on the territory of the Republic of Serbia to be bull dams in year 2002 . Selection of cows for herd of bull dams was carried out subsequent to first lactation, that is based on following lactations. Effect of paragenetic factors, year and season of calving, on reproductive traits (age at first conception, duration of pregnancy, duration of service period and interval between two clavings) was investigated.

Distribution of bull dams was carried out in 10 groups according to year of calving;

\begin{tabular}{|c|c|c|c|c|c|c|c|c|c|c|}
\hline Year & 1993 & 1994 & 1995 & 1996 & 1997 & 1998 & 1999 & 2000 & 2001 & 2002 \\
\hline $\mathrm{N}$ & 7 & 15 & 31 & 52 & 92 & 112 & 162 & 187 & 195 & 28 \\
\hline
\end{tabular}

and in 4 groups according to season of calving;

\begin{tabular}{|c|c|c|c|c|}
\hline Season & I & II & III & IV \\
\hline $\mathrm{N}$ & 187 & 189 & 240 & 265 \\
\hline
\end{tabular}

Calving seasons, or in other words beginning of lactations, were following: I - winter (January, February, March); II - spring (April, May, 
June); III - summer (July, August, September); IV - fall (October, November, December).

Analysis of the effect of paragenetic factors on investigated reproductive traits was carried out using the method of Least Squares (Harvey 1987), using the fixed model:

Where:

$$
\mathrm{Y}_{i j m}=\mu+\mathrm{G} i+\mathrm{S} j+\mathrm{e}_{i j m}
$$

$\mathrm{Y}_{i j m}=$ Demonstration of investigated trait in $m$ cow, born in year $\mathrm{i}$ and season $j$

$\mu \quad=$ general average

$\mathrm{G}_{j} \quad=$ fixed influence of calving year $i$

$\mathrm{S}_{k} \quad=$ fixed influence of calving season $j$

$\mathrm{e}_{i j m}=$ random error

Also the effect of year and season of conception on age at first conception was investigated.

\section{Results of investigation and discussion}

Reproductive maturity in cattle occurs considerably earlier than their full body development. Therefore it is not recommended to fertilize heifers before they reach $2 / 3$ of their body development, or 15-16 months of age, since the organism is not fully developed. By application of the method of least squares average age at first conception of 517,6 days for 292 bull dams was determined (table 1). Insignificantly higher values were obtained by Petrović M. (2000), and considerably higher values relating to age at first conception were obtained by Spasić (1996).

Year and season of conception had no statistically significant effect on investigated trait in this research ( $\mathrm{p}>0.05)$. Skalicki et al. (1991) have established highly significant effect of season of calving on age at first conception.

General average of the mean of least squares for duration of pregnancy corrected for the effect of year and season of calving was 285,51 days.

Effect of the year of calving caused variations in duration of pregnancy and deviation from the general average in interval from-1,19 to 0,85 days $(\mathrm{P}>0,05)$. Season of calving also had no statistically significant effect on duration of pregnancy $(\mathrm{P}>0,05)$. 
Insignificant effect of the season of calving on duration of pregnancy were established in the research of Skalicki et al. (1991), Petrović (2000), and in research carried out by Trifunović et al. (2003) significant effect was determined $(\mathrm{P}<0,05)$.

Average duration of service period of bull dams was 108,98 days. Year of calving had statistically significant influence $(\mathrm{P}<0,05)$ on duration of service period. Different weather conditions have influenced great differences in regard to yield of animal feed on cultivable area, meadows and pastures, and at the same time have also affected the duration of service period. The greatest positive deviation from general average was realized in year $1993(29,99)$, and the greatest negative deviation in 2002 (-35,47 days).

The effect of season of calving on duration of service period was statistically significant $(\mathrm{P}<0,05)$. The longest service period was realized in winter season - 116,99 days, and the shortest in summer season 100,72 . This effect can to some extent be explained as result of the positive influence of green mass used in nutrition as well as influence of sun light in cows which were on pastures. Highly significant influence of season on duration of service period was established by Trifunović et al. (2003), whereas significant effect was established by Petrović M. (2000) and Skalicki et al. (1991). 
Table 1. General average, mean values of least squares and their errors for reproductive traits

Tabela 1.Opšti prosek, srednje vrednosti najmanjih kvadrata i njihove greške reproduktivnih osobina

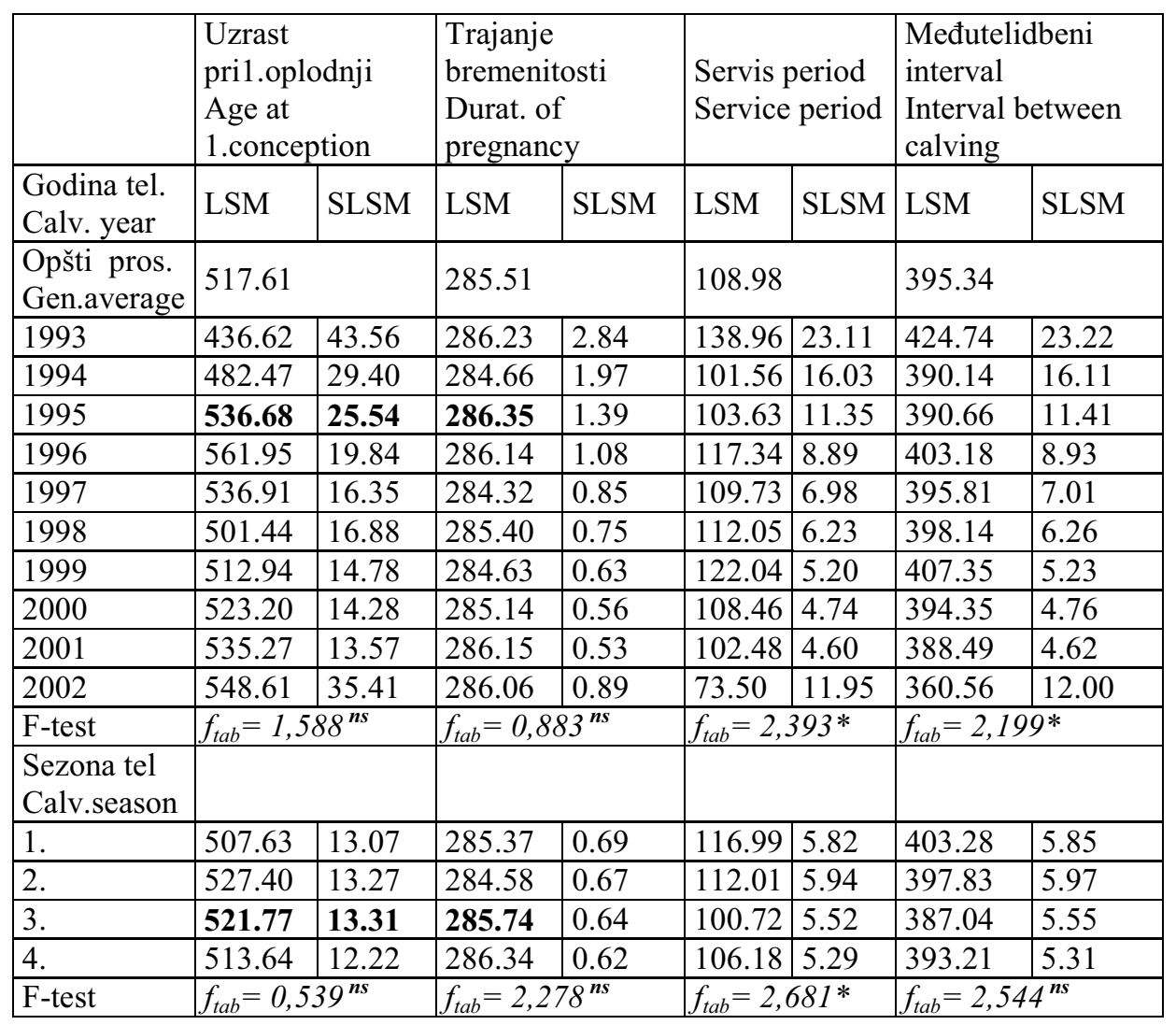

$$
\text { N.S }-\mathrm{P}>0.05 ; *-\mathrm{P}<0.05 ; * *-\mathrm{P}<0.01
$$

Interval between calving is best parameter of cow fertility. Duration of interval between calving is directly related to duration of service period and duration of pregnancy. Interval between calving in average was 395.34 days.

Year of calving had significant effect on period between calving $(\mathrm{P}<0,05)$. The shortest interval between two calvings was determined in year 2001, 388,49 days. Season of calving caused small variation of interval between calvings without statistical significance $(\mathrm{P}>0,05)$. The shortest interval between calvings was determined in heads born in 
summer season - 387,04 days. Petrović M. (2000) established significant effect of season of calving on interval between calvings $(\mathrm{P}<0,05)$.

\title{
Conclusion
}

Demonstration of reproductive traits of bull dams of Simmental breed was on satisfactory level. In future breeding-selection activities effort should be made to enable or realize one calf per year.

General average of the mean of least squares of fertility traits was: for age at first conception - 517.61 days, duration of pregnancy - 285.51 days, duration of service period - 108.98 days, interval between calvings - 395.34 days.

Year of calving influenced statistically significant duration of service period and interval between two calvings $(\mathrm{P}<0,05)$, contrary to age at first conception and duration of pregnancy for which no significant influence was established $(\mathrm{P}>0,05)$.

Season of calving had significant effect on duration of service period $(\mathrm{P}<0,05)$, whereas on other investigated parameters of fertility no significant influence was established $(\mathrm{P}>0,05)$.

\section{REPRODUKTIVNE KARAKTERISTIKE BIKOVSKIH MAJKI SIMENTALSKE RASE}

\author{
V.Pantelić,Z.Skalicki,M.M.Petrović,D.Kučević
}

\section{Rezime}

Ispoljenost reproduktivnih osobina bikovskih majki simentalske rase bila je na zadovoljavajućem nivou. U daljem odgajivačkoselekcijskom radu treba nastojati da se omogući dobijanje jednog teleta godišnje.

Opšti prosek sredine najmanjih kvadrata osobina plodnosti iznosio je za uzrast pri prvoj oplodnji 517.61 dana,trajanje bremenitosti 285.51 dana, trajanje servis perioda 108.98 dana, dužina međutelidbenog intervala 395.34 dana.

Godina telenja statistički je značajno uticala na trajanje servis perioda i dužinu međutelidbenog intervala $(\mathrm{P}<0,05)$, za razliku od uzrasta 
pri prvoj oplodnji i trajanje bremenitosti na koje nije imala značajan uticaj $(\mathrm{P}>0,05)$.

Sezona telenja imala je signifikantan uticaj samo na trajanje servis perioda $(\mathrm{P}<0,05)$, dok na ostale ispitivane parametre plodnosti nije imala značajnijeg uticaja $(\mathrm{P}>0,05)$.

Ključne reči: Reprodukcija, simentalska rasa, bikovske majke, godina i sezona telenja.

\section{Literature}

1. LAZAREVIĆ, R., ROMČEVIĆ, Lj., VASOVIĆ, S., NIKITOVIĆ, N., MIHAJLOV, B. (1985): Varijabilnost proizvodnih i reproduktivnih osobina krava simentalske rase. Savremena poljoprivreda, vol. 33, (1-2) str. 5-16.

2. PANTELIĆ,V.(2004): Fenotipska varijabilnost proizvodnih i reproduktivnih osobina bikovskih majki simentalske rase.Magistarska teza.Poljoprivredni fakultet, Beograd,

3. PETROVIĆ, M. (2000): Ispitivanje dugovečnosti, proizvodnje mleka i mlečne masti krava simentalske rase. Magistarski rad. Poljoprivredni fakultet, Beograd.

4. SKALICKI, Z., LATINOVIĆ, D., LAZAREVIĆ, Lj., STOJIĆ, P. (1991): Fenotipske karakteristike reproduktivnih osobina crno belih goveda sa različitom proporcijom gena holštajn-frizijske rase. Zbornik radova Poljoprivrednog fakulteta, Radovi sa 7. naučnog skupa zootehničara Jugoslavije, Beograd, str. 33-39.

5. SPASIĆ, Z. (1996): Varijabilnost i povezanost osobina mlečnosti i plodnosti tri generacije domaćeg šarenog govečeta. Magistarski rad. Poljoprivredni fakultet. Beograd.

6. TRIFUNOVIĆ, G., LATINOVIĆ, D., ĐEDOVIĆ RADICA, SKALICKI, Z., PERIŠIĆ, P., MEKIĆ, C. (2003): Uticaj određenih paragenetskih faktora na osobine plodnosti populacije crno-belih goveda. Savremena poljoprivreda, vol.52 (3-4) str. 311-316.

7. TRIFUNOVIĆ, G.,LATINOVIĆ, D.,MEKIĆ, C.,ĐEDOVIĆ RADICA,PERIŠIĆ, P.,BUNEVSKI, B.,NIKOLIĆ, R., (2004):Uticaj nivoa prinosa mleka na osobine plodnosti goveda.Biotehnologija $\mathrm{u}$ stočarstvu, vol. 20,(5-6) str.35-40. 